\title{
Austria and the Global Compact on Migration: the'populist securitization' of foreign policy
}

\author{
Patrick Müller ${ }^{1} \cdot$ Charlott Gebauer $^{1}$
}

Accepted: 6 September 2021 / Published online: 29 October 2021

(c) The Author(s) 2021

\begin{abstract}
Bridging arguments between securitization theory and populist communication, this article shifts attention to the strategy of 'populist securitization'. It argues that populist parties may seek to 'securitize' international political issues for the purpose of domestic political mobilization. Empirically, it demonstrates the relevance of populist securitization for the case of Austria's foreign policy on the Global Compact on Migration during the coalition government (2017-2019) between the populist radical right Freedom Party (FPÖ) and the conservative People's Party (ÖVP). The case study of the GCM elucidates the active interest populist parties like the FPÖ take in shaping foreign policy decisions that are close to their domestic political agenda. If successful, populist securitization can have a profound and sustained impact on the public perceptions of foreign policy issues and can create a sense of urgency about the need for an appropriate foreign policy response. In doing so, foreign policy becomes part of the game of domestic politics that can affect foreign policy decisions.
\end{abstract}

Keywords Populism · Securitization · Austria · Global Compact Migration

\section{Introduction}

The rise of populist radical right (PRR) parties in several EU member states has resulted in a growing interest in the implications of populists in government for foreign policy (Dyduch and Müller 2021; Müller et al. 2021), as it is analysed in the introduction to this special issue. Emerging research on populism by international relations scholars frequently treats right-wing populism as an ideology that can inform foreign policy positions and preferences in significant ways, whilst potential links of foreign policy decisions to dynamics related to domestic politics still constitute largely unknown territory. Conversely, scholars of comparative politics who

\section{Patrick Müller}

patrick.mueller@univie.ac.at

1 University of Vienna and Vienna School of International Studies, Vienna, Austria 
regard populism as a phenomenon that belongs to the realm of domestic politics have long shown little interested in its foreign policy implications. Yet, as the parallel processes of Europeanization and globalization are increasingly blurring the boundaries between international and domestic politics, the link between foreign policy issues and the domestic agenda of populist actor and their mobilization of mass followers merits greater attention.

Addressing this research gap, this article shifts attention to what we call the "populist securitization' of foreign policy issues. Bridging between arguments from securitization theory and works on populist communication, we argue that populists may seek to 'securitize' international political issues for the purpose of domestic political mobilization. In particular, we consider populist securitization of foreign policy as a political strategy that combines the discursive securitization of a foreign policy issue with populist appeals to the 'elite-vs-people' divide. Empirically, we demonstrate the relevance of our theoretical argument for the case of Austria's foreign policy towards the 'Global Compact on Migration' (GCM). Whilst Austrian diplomats had played a prominent role in the negotiations leading to the GCM, the coalition government made up of the conservative Austrian people's party (ÖVP) and the rightwing populist Austrian Freedom Party (FPÖ) abstained in the UN General Assembly vote on the pact in December 2018.

As such, the opposition of the FPÖ leadership against the GCM is not surprising and fits well with its critical attitude towards migration. Like populist radical right (PRR) parties more generally, the FPÖ's ideology combines populism with nationalist and xenophobic ideas (Mudde 2007). What is notable, however, is the fact that the FPÖ succeeded in shaping the position of the ÖVP-FPÖ coalition government. With the FPÖ serving as the junior partner in a collation government led by Chancellor Sebastian Kurz from the ÖVP, it could not single-handedly decide on Austria's position on the GCM. The conservative ÖVP had previously supported the GCM, and in his prior function as foreign minister, chancellor Kurz had backed an active Austrian role in the diplomatic negotiations. Not only did the ÖVP adapt to the FPÖ's position on the pact, but it even maintained a critical stance on the GCM after it had formed a new coalition government in 2019 with the Green party that holds liberal views on migration. As we will argue in this article, the change in Austria's official diplomatic position on the GCM was preceded by an intense process of populist securitization and mobilization against the pact. The FPÖ's populist securitization discourse-which was amplified by the activities of transnational communication networks of right-wing groups and influencers-turned the GCM from a rather technical affair into a high-profile issue that was increasingly depicted as a substantive threat to Austria's sovereignty and ability to control migration and manage related risks. This also increased the pressure on the ÖVP-led coalition government to adopt a critical position on the GCM.

Besides relevant academic literature, our analysis draws on a broad range of primary sources including media reporting and press articles as well as the social media communication of leading FPÖ representatives on Facebook. Research has 
shown that populist communication strategies tend to rely more on Facebook than other social media platforms. ${ }^{1}$ The official Facebook page of the FPÖ, the Facebook pages of all Freedom Party officials that were in government during the period under investigation (September-December 2018), as well as the Facebook accounts of two other prominent party representatives (Harald Vilimsky - the FPÖ's MEP and Manfred Haimbuchner-Deputy Federal Party Chairman of the FPÖ) known for their power basis within the FPÖ were screened. ${ }^{2}$ Overall 159 posts were examined and analysed relying on basic insights from framing theory (Benford and Snow 2000; Gamson 1992).

Moreover, three in-depth semi-structured expert interviews were conducted. The article will proceed as follows: first, we develop our theoretical argument, identifying core observable aspects of populist securitization strategies. Subsequently, we analyse key elements of the FPÖ's populist securitization strategy. Moreover, we evaluate the success of populist securitization of the GMC, both in terms of mobilizing the public against the alleged threats posed by the pact and its supporters and in terms of its consequences for shaping Austria's on the GCM. The conclusion highlights our main findings and discusses their implications for future research.

\section{The populist securitization of foreign policy}

Our argument about the populist securitization of foreign policy bridges between the 'Copenhagen school's' securitization theory and works on populism as a communication strategy (Stanyer et al. 2016; de Vreese et al. 2018). In particular, populist securitization constitutes a discursive strategy that combines familiar securitization practices with core populist appeals centring on the 'elite-vs-people' divide. Works that are concerned with populists as strategic communicators focus on the intentional use of rhetoric style and means to mobilize domestic support (Barr 2018; Wodak 2015; Wodak et al. 2021). Wodak (2015: 6-7, 90-95) argues that the discourse of populist actors may seek to mobilize imagined and created threats to introduce legislation and to legitimize attacks on prevailing institutions and the rule of law, which she has described as 'shameless normalization'. If successful, this can lead to a situation where the extremist language, instruments and political agenda of the radical and the far right is mostly supported by mainstream conservative parties, producing a shift from the periphery of such acts to the centre (Wodak 2015). Similarly, populist securitization can lead to a situation where mainstream parties adapt their positions and rhetoric to the discourse of populist actors, particularly when they find a strong resonance with the public and are successful in mobilizing voters (Bayerlein 2021a,b). As such, populist securitization can even have an effect on politics in situations where populist actors are not in power.

\footnotetext{
1 When conducting a preliminary exploratory search on Twitter, it was found that the Austrian government politicians, did not post on the GCM apart from a few single posts made by some politicians.

${ }^{2}$ Keyword such as 'Migrationskompakt' and 'UN-Migrationspakt' were utilized in the search function of the politician's Facebook pages.
} 
Works that are closely related to the perspective of populism as a 'political strategy' tend to treat populist actors as flexible, opportunistic vote seekers that are concerned with domestic political gains (Weyland 2017: 64). For populists as strategic communicators, the securitization of international issues offers important strategic benefits. Securitization involves the intersubjective establishment of an existential threat through the discursive exchange between the securitizing actor and an audience, demanding urgent and immediate attention as well as extraordinary measures to counter the threat (Buzan et al 1998: 24-24). What constitutes a security issue is thus not principally related to the 'reality' of a threat, but it must be discursively constructed by securitizing actors (Buzan et al. 1998). Here, the securitization of international issues increases their potential as issues for effective domestic communication and mobilization. In particular, securitization processes are understood to proceed in form of a 'securitization spectrum', where an issue can move from being non-politicized, to politicized, to securitized (Emmers 2016: 169).

Whilst non-politicized issues do not figure prominently in public debates and are not a concern for state policies or actions, politicized issues become 'part of public policy, requiring government decision and resource allocation (Buzan et al. 1998: 23). Populist actors have acquired a reputation for politicizing issues like migration, raising them to the public sphere, spreading information and appealing to emotions (Moffitt 2020). By securitizing an issue, populist actors can raise the public salience of an issue even further, turning it into a central issue of public concern and calling for 'emergency actions' beyond the state's standard political procedures. Besides amplifying public attention, securitization also has important psychological effects that play into the hand of populist actors. Importantly, through securitization, populists can elicit feelings of fear and insecurity that have been shown to advance the mobilizing potential of their appeals (Homolar and Scholz 2019; Wirz 2018). In particular, research on populist communication and mobilization has shown that populist claims are often more successful when relying on emotions, rather than on facts and rational arguments (Wirz 2018; Hameleers et al., 2017; Canovan 1999: 6).

From the perspective of populist actors, it is not important that a particular threat subject to securitization is genuine or 'real', as long as it helps the purpose of domestic mobilization through populist communication. At the same time, the ability to successfully securitize a new issue will depend on the particular social and institutional environment, in particular the way in which the securitization of a new issue can be effectively related to prior images and narratives legitimized in a given social context (Rychnovská 2014; Balzacq 2010).

To analyse the discourse of populist securitization, we draw on basic insights from framing theory. In particular, we rely on the technique of categorizing frames, which considers framing as a 'struggle' and a 'negotiation' of meaning (Benford and Snow 2000; Gamson 1992). Framing actors seek to 'negotiate a shared understanding of some problematic condition or situation they define as in need of change, make attributions regarding who or what is to blame, articulate an alternative set of arrangements and urge others to act in concert to affect change' (Benford and Snow 2000: 615). Linking securitization and populist communication practices, we understand populist securitization strategies to involve the following three framing elements: (i) the portrayal of an international issue as a threat to the security of 'the 
people' as the main reference object (threat frame); (ii) 'anti-establishment' appeals that ascribe responsibility or blame the established elite, undermining confidence in its willingness and ability to effectively address these external threats (anti-establishment frame); and (iii) appeals to 'people centrism' that demonstrates closeness of populist actors with the people by protecting them from the diagnosed threats by offering adequate solutions and calls for action (people-centric frames). ${ }^{3}$

In the context of populist securitization, populists act as 'securitizing actors' on a given international issue (referent object) that is framed as a threat to the security of 'the people'. Threat frames can address different categories of the concept of security, including political security (i.e. national sovereignty), economic security (national economies), societal security (collective identities) and environmental security (species and habitats). At the same time, threat frames may also involve more specific referent objects, such as trade deals (Sohn and Koo 2011; Capling and Ravenhill 2012) or state borders (Salter and Piché 2011). Here, foreign policy issues can be a useful target for the mobilization through populist securitization. By focusing on foreign policy issues populist actors can expand their anti-elite appeals to external agents and problems, which can be particularly useful for populists in government that have assumed the responsibility of ruling their countries.

Populist securitization combines securitization moves that advance the mobilization potential of an issue with frames that centre on the elite-people divide (de Vreese 2018: 427). 'Anti-establishment' appeals and appeals to 'people centrism' are commonly understood as essential elements of populist rhetoric (Aalberg et al. 2017; de Vreese 2018). This relates to the core of populist ideology, which 'considers society to be ultimately separated into two homogeneous and antagonistic groups, "the pure people" versus "the corrupt elite", (Mudde 2004: 526). Antiestablishment frames generally involve blaming 'the elite' for betraying the people and for failing to defend the people's interests. Here, the elite is often held responsible for things that go wrong and the problems people are facing (Spruyt et al. 2016). Frequently, the elite is portrayed as weak, self-serving and detached from the people. In the context of populist securitization, anti-establishment frames seek to promote the view that the 'political elite' is not able, or unwilling, to provide effective protection from an alleged threat (Wirz 2018).

Conversely, appeals to 'people centrism' express the commitment of populist actors to promote the homogeneous will of the people. When it comes to PRR parties, their shared emphasis on ethnonationalism translates into ethnically defined notion of the people (Rydgren and Van der Meiden 2019: 439). Here, populist actors promote themselves as the true defenders of the people and their cultural identity from international threats, providing relief and reassurance. People-centric frames offer protection from diagnosed security threats and risks that serve as the reference object of their own populist securitization moves (see also Homolar and Scholz

\footnotetext{
3 'Threat frames' and 'anti-establishment' frames relate to what Benford and Snow (1988: 199-202) describe as 'diagnostic' framing, which defines and explains a certain situation that ascribes responsibility or blame. Conversely, 'people-centric' frames make use of 'prognostic' and 'motivational' framing, providing solutions to a diagnosed problem and calling for action to change a situation.
} 
2019: 360). As such, they propose solutions to a diagnosed problem and call for action.

As a communication strategy that aims at domestic mobilization, populist securitization can be judged as successful if it raises public attention of an issue, results in high audience acceptance of populist securitization frames and contributes to the mobilization of domestic constituencies on the elite-vs-people divide. At the same time, moving an issue from 'politicization' to 'securitization' can also create a sense of urgency to adopt emergency measures to counter an alleged threat (Homolar and Scholz 2019). Basic indicators for successful populist securitization are that the target audience starts to perceive the securitized issue as a matter of high political salience, accepts the system of meaning constructed through populist securitization frames and becomes involved in contentious political action against the issue (Jansen 2011).

Accordingly, populist securitization may also involve audience mobilization against an identified threat (e.g. Buzan 1998; Roe 2008), increasing the pressure on policymakers to adopt appropriate measures to counter security threats and challenges. By successfully securitizing an issue in the public discourse, populists thus may also change the political perceptions and opportunity structure associated with foreign policy options, facilitating measures to counter an identified threat. As such, the strategy of populist securitization speaks to broader, overarching research questions raised in this special issue that are concerned with how populism impacts on foreign policy processes and outputs. Whilst previous works have predominately focused on factors related to the direct influence and leverage of a (junior) coalition partner on foreign policy decisions - such as its party unity, the occupation of cabinet positions with authority over foreign policy and the ability to threaten the stability of the government (Verbeek and Zaslove 2015)—populist securitization points to a more indirect route of influence. Moreover, by addressing the way in which foreign policy issues may become instrumentalized for the domestic aims of populist actors, this article also contributes to the question of what is distinctive in the foreign policy of populist (see introduction to the special issue).

\section{A case of populist securitization of foreign policy}

Adapted under the support of the United Nations (UN), the Global Compact on Migration (GCM) is a non-binding agreement covering key aspects of international migration in a universal approach (UN 2016). The agreement emphasizes that all migrants are entitled to universal human rights and aspires to eliminate all forms of discrimination, including racism, xenophobia and intolerance against migrants and their families. Simultaneously, the GCM explicitly reaffirms the sovereign right of states to determine their national migration policy (UN 2018). Austria's role in the early stages of negotiating the UN migration pact corresponded with its traditional diplomatic profile as an active supporter of multilateralism and a reliable partner at the UN. In September 2016, the UN General Assembly anonymously adopted the New York Declaration for Refugees and Migrants (UN 2016), which committed UN Member States to work towards the adoption of a Global Compact for Safe, Orderly 
and Regular Migration (GCM). On this occasion, the then Austrian foreign minister Sebastian Kurz declared that:

...if immigrants find a job and contribute to our societies then integration can be a win-win situation for all of us. [....]. We need to join forces [....]. No country has the capacity and resources to take in unlimited numbers of migrants. This is a global challenge and a shared responsibility (Austrian Foreign Ministry 2016).

In the subsequent negotiation process, Austria's diplomacy took on a central role in acting as a common European voice in the negotiations of the GCM that took place in the period between February and July 2018. Encouraged by its EU partners, Austria actively offered its services to represent the EU in the negotiations. When by mid-July a draft text was established after several rounds of negotiations, the Austrian conservative-led coalition government gave no signs that it had any substantive criticism or reservations about the text. On 13 July 2018, the final version of the GCM was approved by all 193 member UN nations except the USA, which earlier had declared that it would not take part in the negotiations (CNN 2018). When the pact was formally endorsed on 17 December 2018 by the UN General Assembly (UNHCR 2018) - with 152 countries voting in favour of the resolution-the USA, Hungary, Israel, the Czech Republic and Poland voted against it. Moreover, in total 12 countries, including Austria abstained the vote.

The internal EU divisions over the GCM are symptomatic of a situation where migration has become a highly politicized and contested issue within the EU and between its Member States ever since the political crisis in 2015, which has accentuated pre-existing divides among Member States (Schmidt 2019). Whilst much of Austria's foreign policy establishment viewed the government's official position as a break with established diplomatic principles and norms, Austria's Freedom Party (FPÖ) early on mobilized against the pact. Focusing on the GCM as the referent object of securitization, the FPÖ's discourse combined securitization practices with populist appeals. In addition to communication through leading Austrian news outlets, direct communication through social media played a significant role in the FPÖ's mobilization against the compact.

\section{The freedom party and the securitization of the GMC}

The FPÖ's approach to the GCM did not take place in a political vacuum but could tap into its broader discourse on migration that has long been known for its anti-immigration rhetoric and web-based mediatization (Forchtner et al. 2013). Under its chairman Heinz Christian Strache, migration was increasingly connected to the issue of crime and domestic security (Lehner 2019: 51; Forchtner et al. 2013) as well as to socio-economic grievances (Heinisch and Wegscheider 2018). Migration was frequently portrayed as a serious challenge to the public security, Christian cultural identity and social cohesion of the Austrian people. Whilst a focus on immigration is not limited to Strache and the FPÖ, it characterizes the far right/radical right as such. An analysis of more than 600 Facebook 
Table 1 Populist securitization: frames and actors

\begin{tabular}{lllll}
\hline FPÖ representative & $\begin{array}{l}\text { Total number of } \\
\text { posts with reference } \\
\text { to GCM }\end{array}$ & $\begin{array}{l}\text { Posts refer- } \\
\text { ring to threat } \\
\text { frames }\end{array}$ & $\begin{array}{l}\text { Posts referring to } \\
\text { anti-establishment } \\
\text { frames }\end{array}$ & $\begin{array}{l}\text { Posts referring } \\
\text { to people-centric } \\
\text { frames }\end{array}$ \\
\hline $\begin{array}{l}\text { Heinz Christian } \\
\quad \text { Strache }\end{array}$ & 53 & 38 & 20 & 15 \\
$\begin{array}{l}\text { Harald Vilimsky } \\
\text { Herbert Kickl }\end{array}$ & 68 & 33 & 21 & 9 \\
Mario Kunasek & 91 & 17 & 7 & 4 \\
$\quad$ Norbert Hofer & 4 & 10 & 3 & 3 \\
$\begin{array}{l}\text { Manfred Haimbu- } \\
\text { chner }\end{array}$ & 4 & 0 & 2 & 0 \\
$\begin{array}{c}\text { Total \# of posts } \\
\text { analysed }\end{array}$ & 159 & 0 & 1 & 31 \\
\hline
\end{tabular}

posts by Strache published in 2019 found that migration was the most prominent issue in his social media communication, whilst the vast majority (85 per cent) of his posts that dealt with security did so in connection with migration issues (Kontrast 2019). Given the international nature of the GCM, it not only connected to well established discursive positions on migration as a threat to societal security but it also related to the issues of national control and popular sovereignty. Moreover, according to a Eurobarometer poll conducted in spring 2018, immigration was seen as the most important issues facing the EU for 38\% of European citizens (European Commission 2018). More specifically, when asked about the main concern at the national level, immigration was at first place in Austria, with a total of $29 \%$ saying that it was the biggest challenge Austria was facing (ibid.).

Interestingly, the GCM initially generated little interest by the FPÖ leadership during the official negotiations of the pact, as it was seen as a rather technical foreign policy issue of little political relevance. However, by September 2018 a social media campaign by right-wing populist activities and transnational networks had moved the GCM into the focus of the FPÖ leadership. On 10 September 2018, vice chancellor Strache stated in the boulevard newspaper 'Kronenzeitung' that he was 'absolutely critical' of the pact (der Standard 2018b). With almost 800,000 followers on Facebook, the highest number of any politician in Austria in 2018, Strache dedicated almost 80 per cent of his posts dealing with foreign policy issues to the GCM (Kontrast 2019). The social medial campaign by the FPÖ and right-wing influencers-which included distorted interpretations and misinformation about the GCM — soon gained considerable traction, resulting in a large-scale spike in social media activities in October (Politico 2019).

Table 1 shows the overall results of the Facebook analysis. The posts were allocated to the different frames, when they made reference to the different categories. Many of the posts mentioned multiple or all frames in one post; some posts did not refer to any of the frames but only explicitly mentioned the GCM.

The FPÖ framed its growing criticism of the pact in strong securitizing language, portraying it as a challenge to Austria's sovereignty and autonomy as well as the 
public security of the Austrian people. Out of the 159 statements of leading FPÖ representatives on the GCM posted on Facebook in the period from September until December 2018, 98 used a threat frame, testifying of the strong securitization of the discourse (see table below). A prominent threat frame utilized by the FPÖ was that the GCM constituted a threat to Austria's sovereignty and self-rule (24 threat frames). Among other things, it was stated that the signing of the GCM would put 'Austria's sovereignty at risk' (Strache 2018b) and that migration can and 'must never become a human right' (Strache 2018d). Similarly, it was stated that Austria's sovereign and 'autonomous self-determination' (Strache 2018m) had to be 'protected from creeping outside determination' (ibid.). Following Austria's decision to abstain, the FPÖ framed Austria's abstention as a choice for 'self-determination' as opposed to 'external control through the back door!' (Strache 2018h; Kickl 2018e). Simultaneously, the GCM was criticized for extending the 'reasons for flight to include climate, poverty and economic refugees' (Strache 20181), hence increasingly limiting the capacity of governments to control migration (ibid.).

In addition to portraying the GCM as a threat to Austria's sovereignty, it was also framed as a threat to the societal security and socio-economic well-being of the Austrian people. A Facebook post by vice chancellor Strache stated, for instance, that the GCM 'comes from the pen of people who apparently have not read any crime statistics and who have never studied the business model of the international smuggling mafia and the smuggling industry' (Strache 2018g). Moreover, it was argued that certain provisions of the GCM could lead to a situation where 'persons that fled illegally into the country' would obtain a right to access the Austrian labour market and its social security system (Kronezeitung 2018; Kleine Zeitung 2018). The warnings of the negative consequences of the GCM were supplemented by criticism of positive interpretations of migration as 'a source of prosperity, innovation and sustainable development' (Kickl 2018b), which were described as 'undifferentiated' (ibid.) by the Minister of interior. Emphasizing the threat the GCM would pose to the living conditions of the Austrian people, interior minister Kickl, in another post, demanded action to prevent the acceptance of the agreement: 'We must ensure that migration does not worsen the living situation of Austrians. We do this by rejecting the UN migration pact (...)' (Kickl 2018d). The statements made from leading representatives of the FPÖ in the mainstream media and in the social media made particular use of threatening language and emotional appeals to fear. Among other things, the pact was referred to as a 'pact of the devil' (Strache 2018o) and 'wolf pact' (ibid.) that would have 'fatal consequences' (Strache 2018b). At the same time, the explicit labelling of migrants as 'illegal' (Vilimsky 2018d) and 'irregular' (Strache 20181) further projected an imagery of people that are illicit and perilous, constructing an immediate symbol of threat to the Austrian people.

The FPÖ, moreover, invoked cultural identity threats in relation to the GCM. Strache (2018p) posted that 'it is still us who decide who comes to us, who is allowed to work for us, who receives social benefits and who illegally or legally enters!'. Moreover, many posts by FPÖ politicians like one by Kunasek (2018b) declared that Austria and its government must 'protect the native population' from the GCM. These posts all signified that the Austrian people belonged to a group (the people), to which migrants and refugees did not belong. Using dramatic and scandalizing 
language, it was even asserted that the GCM would 'trigger a suction effect', that would 'bring new waves of migration to us' (Vilimsky 20181).

\section{Securitization and populist appeals: constructing the 'elite-people divide'}

The FPÖ's discourse on the GCM frequently combined securitizing language with populist messages that used frames centring on the 'elite-people divide'. In terms of the social media communication of leading FPÖ representatives, 54 out of a total of 159 of their Facebook posts on the GCM used a frame that referred to the people-elite divide. As such, the FPÖ's populist discourse not only mobilized against the alleged risks posed by the GMC and its supporters, but also promoted the image of the FPÖ as the defender of the people against these risks.

The FPÖ's anti-establishment' frame depicted the elite as encompassing different national and international agents that were made responsible for creating and fostering the threat posed by the GCM. At the international level, Germany's chancellor Angela Merkel, as well as supranational EU institutions (most commonly the European Commission), were identified as central advocates of the pact, who according to the FPÖ sought to pressure sceptical governments to consent to it (Vilimsky 2018c, d, e). Within Austria, the Social Democratic Party of Austria (SPÖ) and the media were identified as part of a self-serving establishment that was largely indifferent to the real interests of the Austrian people. Among other things, it was argued that Austria's political elite-most notably the Social Democrats that supported the GMC - would have signed the pact that was not in the best interest of the Austrian people. A post by Mario Kunasek, Minister of Defence (2018a), even showed a video created by the FPÖ, which stated that the socialist party would have signed the compact.

Moreover, Austrian supporters of the pact were frequently portrayed as being 'naïve' (Kickl 2018a), incompetent or even purposefully misleading about the threat posed by the pact and its problematic consequences. Social media communication by the FPÖ discredited the 'media elite' by suggesting that Austria's public television and other Austrian media did not report on the problematic consequences of the pact (Strache 2018a). At the same time, global elites were blamed for their promotion of the GMC. Among other things, it was argued that the German government tried to promote the GCM in secrecy (Vilimsky 2018i). The FPÖs anti-establishment discourse was complemented by enunciated messages focusing on the "people' (people centrism). Here again, the people were rendered in various ways, most notably in terms of the people as a sovereign group, as a nation and as the population. Simultaneously, familiar populist rhetoric relying on wordings like 'us', 'them', the 'Austrian people', 'our' and 'solidarity' displayed the FPÖ closeness to the people. Repeatedly, the FPÖ portrayed itself as the saviour of the Austrian people who resisted the GMC and protected the people from its dangerous consequences, as opposed to the global and Austrian elites that betrayed the real interest of the people and put their security at risk by promoting the GMC (Strache 2018e). Phrases like 'we make politics for the Austrians, not for the globalists' (Haimbuchner 2018), that the FPÖ was 'putting solidarity with one's own people at the centre of politics' 
(Kickl 2018b) or that it felt 'obliged exclusively to its own people and to Austrian sovereignty' (Strache 2018h) were commonplace. Against this backdrop, the FPÖ's discourse used the GMC to demonstrate the party's loyalty to Austria and its people, with speaking out against the GMC becoming synonymous for speaking in favour of Austria's sovereignty (Kickl 2018c).

Whilst the securitization discourse on the GMC depicted the pact as a source for insecurity, risks and uncertainty, the FPÖ promoted itself as a guarantor of 'order, clarity and control in the area of asylum and migration policy' (Kickl 2018f). The FPÖ emphasized that it stood for a 'clear and recognizable strategy/line' (FPÖ 2018 c) on 'the question of migration' (ibid.), protecting the people from the threats posed by the GMC and its problematic consequences. In the FPÖ's discourse on the GMC, it was repeatedly emphasized that the FPÖ had 'successfully prevented and rejected the UN migration pact for Austria' (Kickl 2018b), turning it into an international role model and leader in the resistance against the pact (Strache 2018f, i, n; FPÖ 2018a). In this vein, it was frequently stated that Austria played a 'courageous' (Strache 2018k) and 'pioneering' (Kunasek 2018a) role whilst 'attracting more and more countries that also reject the UN migration pact!' (Strache 2018k).

\section{The success of populist securitization: domestic mobilization and Austria's official position on the GCM}

According to the Institute for Strategic Dialogue (IDS) that examined Twitter-tweets as well as posts on YouTube and Facebook, right-wing populist actors played a disproportionate role in influencing public discussion of the GMC and in raising the public profile of the issue, which previously was hardly noticed on social media (ibid.). In parallel, Austrian boulevard newspapers and other media outlets began to write increasingly negative about the migration pact (derStandard 2018b). The mobilization against the pact by leading FPÖ representatives, right-wing groups and influencers turned the GCM into a salient political issue that triggered a high level of public engagement on social media and featured prominently in traditional media outlets. Indicating the high public profile of the GCM, a survey conducted in November 2018 found that at that time the vast majority of the Austrian population were aware of the pact, with only 9 per cent stating that they did not know what the GCM was (Profil 2018). The survey also indicated that large segments of the Austrian public took a decidedly negative attitude towards the GCM, with 49 per cent of Austrians voicing their support for the government's position not to support the pact, whilst only 29 per cent disagreed with it.

The FPÖ's populist communication strategy raised the public profile of the GCM, creating a strong resonance for its anti-establishment and people-centrist appeals. At the political level, the FPÖ's public mobilization against the pact and its supporters increased the pressure on the ÖVP in the coalition government to adapt to the FPÖs political position. Then, vice chancellor Strache was the first member of the government to publicly declare his criticism of the GCM in September 2018. Moreover, Strache repeatedly stated that core aspects of the pact were opposed to key objectives of the government's coalition agreement (ORF.at 2018b). The pressure placed 
by the FPÖ on the ÖVP was substantive and the ÖVP had already in the past taken over key demands made by the FPÖ in relation to migration and refugee policy to increase their voter share (Rheindorf and Wodak, 2019). Given the FPÖ's successful public mobilization against the GCM, there was considerable public support for the FPÖ line (ibid.) that further augmented the pressure on the ÖVP and empowered the hard-liners on migration policy within the party leadership (interview 2). Against this backdrop, chancellor Sebastian Kurz, who in his previous function as foreign minister had supported the pact, opted to support core arguments of the FPÖ's securitization narrative which was widely interpreted as giving in to political and public pressure (interviews 1,2$){ }^{4}$

As noted by a senior Austrian diplomat, the efforts of the ÖVP leadership soon centred on limiting the negative consequences of adopting a critical position on the GMC for Austria's diplomacy. Leading ÖVP representatives as well as Austria's foreign minister Karin Kneissl — an independent without official party membership who had been nominated by the Freedom Party - sought a political compromise in which Austria would abstain from (rather than reject) the GCM, arguing that the migration pact was not legally binding (interviews 1,2). Reportedly, the vice-chancellery headed by FPÖ leader Strache had sent text modules for the official position on the GCM to the cabinet of foreign minister Karin Kneissl, whose ministry was largely side-lined in the decision-making process on the GCM (die Presse 2018). Simultaneously, foreign minister Kneissl faced significant concerns within the foreign ministry that Austria's changed position would harm its diplomatic reputation (die Presse 2019).

In mid-October, chancellor Sebastian Kurz announced that his government disagreed with 17 out of the 23 points of the GCM (Austrian Federal Chancellery 2018). Chancellor Kurz further stated that the Austrian government would not sign the GCM because the text did not differentiate between 'migration' and 'asylum', arguing that by not signing the compact the Austrian government would hinder the text becoming customary law (Kurier 2018a). Subsequently, Austrian government officials continued to refer to 'national interests', 'sovereign principles' and the need of separating 'legal' and 'illegal' immigration (Kurier 2018b) as reasons for their rejection. When the Austrian government finally opted for abstention, its official position on the GCM continued to raise considerable criticism and concern from legal experts and large circles of its foreign policy establishment (ORF.at 2018a). These concerns were reinforced by the 'poor' technical quality of Austria's official statement. Rather than relying on the official UN translation of the text of the GCM, Austria's official statement included incorrect translations, using expressions such a 'planned migration' instead of 'regular migration' or 'criminal profiling' instead of 'migrant profiling', which had also figured prominently in the communication and websites of right-wing actors mobilizing against the GCM (see below) (Austrian Parliament 2018; Saxony Office for Constitutional Protection 2016).

\footnotetext{
${ }^{4}$ Interview 1 with a senior Austrian diplomat, 5 March 2021, Vienna; Interview 2 with an legal expert, 26 January 2021, Vienna.
} 
Besides stating the official position of Austria vis-a-vis the media, chancellor Kurz and his party preferred to stay largely silent about the GCM (notably on social media), which formed a stark contrast to the FPÖ's active strategy of public mobilization against the GCM. After the ÖVP-FPÖ coalition government had collapsed in May 2020, chancellor Kurz and the ÖVP leadership resisted calls to reverse course under their new coalition government with the Green Party. Though the Green Party has been a vocal supporter of the GCM and propagates liberal positions on migration, ÖVP representatives made clear that the governments' position remained unaltered. This affirms the potential of populist securitization strategies to 'lock-in' a foreign policy position and to dominate public discourse on migration by mainstreaming their positions.

\section{Conclusion}

Populist securitization practices can have a significant and sustained impact on foreign policy that goes beyond its discursive dimension. Amplified by the social media activities of right-wing groups and activists, the FPÖs populist discourse combined the securitization of the GCM with familiar populist appeals that centre on the 'elite-people' divide. In particular, the GCM was used as an opportunity to position the FPÖ as the main defender of the 'real' interests of the Austrian people against the alleged challenges posed by migration. This strategy of populist securitization not only succeeded in mobilizing significant segments of the public against the pact and its supporters, it also generated significant pressure on the ÖVP-led government and its chancellor Sebastian Kurz to accommodate the critical line advocated by the FPÖ leadership. Whilst much of the foreign policy establishment, as well as leading legal experts, remained unconvinced about key arguments used by the FPÖ leadership against the GCM, they were largely side-lined in the foreign policy-making process. Instead, the large-scale populist mobilization against the GCM, in conjunction with political pressure by the FPÖ leadership, shaped the position of the ÖVP/FPÖ coalition government. The fact that the ÖVP maintained a critical position on the GCM even after it had formed a new government with the Green Party - that stands for a more liberal agenda on migration-testifies to the lasting influence established by a domestic political discourse dominated by securitizing language and populist appeals.

For scholars of securitization, the case of Austria's discourse on the GCM shows that securitization may follow an instrumental logic that combines domestic mobilization against a threat with traditional populist mobilization along the elite-people divide. This suggests that political motives other than justifying extraordinary measures to counter a security threat can be important to understand securitization moves. As such, further research focusing on the way populists strategically employ securitization practices to further their domestic political agenda can enhance our understanding of key questions posed by the Copenhagen school, such as who securitizes, on what issues, for whom, why and with what results. For scholars interested in the relationship between populism and foreign policy, in turn, our findings suggest the need to pay greater attention 
to motives and dynamics related to politics. Given the prominent role that domestic political mobilization around the 'elite-people' divide plays for populist actors in the domain of domestic politics, further research is needed to establish the extent to which domestic rationales and dynamics dominate their approach to foreign policy. From the perspective of populism as a political strategy, populist actors will approach foreign policy making in a tactical, flexible and selective way, using foreign policy making as an instrument to further their domestic political agenda.

Acknowledgement This article is based upon work from COST-Action ENTER (CA17119), supported by COST (European Cooperation in Science and Technology).

Funding Open access funding provided by University of Vienna.

Open Access This article is licensed under a Creative Commons Attribution 4.0 International License, which permits use, sharing, adaptation, distribution and reproduction in any medium or format, as long as you give appropriate credit to the original author(s) and the source, provide a link to the Creative Commons licence, and indicate if changes were made. The images or other third party material in this article are included in the article's Creative Commons licence, unless indicated otherwise in a credit line to the material. If material is not included in the article's Creative Commons licence and your intended use is not permitted by statutory regulation or exceeds the permitted use, you will need to obtain permission directly from the copyright holder. To view a copy of this licence, visit http://creativecommons.org/licen ses/by/4.0/.

\section{References}

Austrian Federal Chancellery. 2018. Ministerrat lehnt Beitritt zu UN-Migrationspakt ab - Nachrichten aus der Bundesregierung - Bundeskanzleramt Österreich, 2018, available at https://www.bunde skanzleramt.gv.at/bundeskanzleramt/nachrichten-der-bundesregierung/2017-2018/ministerratlehnt-beitritt-zu-un-migrationspakt-ab.html. Accessed February 2021.

Austrian Foreign Ministry of Affairs. 2016. Address by Foreign Minister Sebastian Kurz on the occasion of the UN High-Level meeting on Refugees and Migrants in New York - BMEIA, Außenministerium Österreich, 2016, available at https://www.bmeia.gv.at/en/the-ministry/press/speeches/2017/2016/ 09/address-by-foreign-minister-sebastian-kurz-on-the-occasion-of-the-un-high-level-meeting-onrefugees-and-migrants-in-new-york/. Accessed February 2021.

Austrian Parliament. 2018. Nationalrat: Scharfe Kritik der Opposition am Ausstieg aus dem UN-Migrationspakt (PK-Nr. 1308/2018), 2018, available at https://www.parlament.gv.at/PAKT/PR/JAHR_ 2018/PK1308/index.shtml. Accessed February 2021.

Bayerlein, M. 2021 'Chasing the Other "Populist Zeitgeist"? Mainstream Parties and the Rise of RightWing Populism', Politische Vierteljahresschrift, 1-23. Presentation of the reference; please normalize.

Balfour et al, R. 2016. Europe's Troublemakers: The Populist Challenge to Foreign Policy, European Policy Centre, available at https://wms.flexious.be/editor/plugins/imagemanager/content/2140/PDF/ 2016/Europe_s_troublemakers_complete_book.pdf.

Balzacq, Thierry, ed. 2010. Securitization theory: How security problems emerge and dissolve. London: Routledge.

Barr, R.R. 2018. 'Populism as a political strategy', in Routledge handbook of global populism ed. Carlos de laTorre. Routledge. https://doi.org/10.4324/9781315226446-4

Bayerlein, M. 2021b. 'Chasing the Other "Populist Zeitgeist"? Mainstream Parties and the Rise of RightWing Populism. Politische Vierteljahresschrift. https://doi.org/10.1007/s11615-021-00299-x.

Benford, R.D., and D.A. Snow. 2000. Framing Processes and Social Movements: An Overview and Assessment. Annual Review of Sociology 26 (1): 611-639. 
Buzan, B., et al. 1998. Security: A New Framework for Analysis. Boulder: Lynne Rienner Publishers.

Canovan, M. 1999. Trust the People! Populism and the Two Faces of Democracy. Political Studies 47 (1): $2-16$.

Capling, A., and Ravenhill, J. (2012) 'The TPP'. In C. L. Lim, D. K. Elms, and P. Low (eds). The TransPacific Partnership: A Quest for a Twenty-first Century Trade Agreement. Cambridge: Cambridge University Press, pp. 279-298, https://doi.org/10.1017/CBO9781139236775.025.

Chryssogelos, A. (2017) 'Populism in foreign policy'. In Oxford Research Encyclopedia of Politics.

CNN, F. K. (n.d.) US quits UN Global Compact on Migration, CNN, available at https://www.cnn.com/ 2017/12/03/politics/us-global-compact-migration/index.html. Accessed February 2021.

Copelovitch, M., and J.C.W. Pevehouse. 2019. International Organizations in a New Era of Populist Nationalism. The Review of International Organizations 14 (2): 169-186.

derStandard. 2018a. Österreich wird UN-Migrationspakt nicht unterzeichnen, 2018, derStandard, available at https://www.derstandard.at/story/2000090390933/oesterreich-zieht-sich-aus-globalem-unomigrationspakt-zurueck. Accessed February 2021.

derStandard. 2018b. Rechte Argumente für Österreichs Nein zum Migrationspakt, 7 November 2018, derStandard, available at https://www.derstandard.at/story/2000090774730/migrationspakt-rechteargumente-fuer-oesterreichs-nein. Accessed February 2021.

diePresse. 2018. Wie das Nein zum Migrationspakt zustande kam, 2 November 2018, Die Presse, available at https://www.diepresse.com/5523458/wie-das-nein-zum-migrationspakt-zustande-kam. Accessed February 2021.

diePresse. 2019. Kneissl soll wegen UN-Migrationspakt-Debatte vor Rücktritt... I DiePresse.com, 2019, available at https://www.diepresse.com/5573855/kneissl-soll-wegen-un-migrationspakt-debattevor-rucktritt-gestanden-sein. Accessed February 2021.

Dyduch, J., and Müller, P. 2021. Populism meets EU Foreign policy: The de-Europeanization of Poland's Foreign Policy Towardthe Israeli-Palestinian Conflict. Journal of European Integration 43 (5): 569-586.

Engesser, S., N. Ernst, F. Esser, and F. Büchel. 2017. Populism and Social Media: How Politicians Spread a Fragmented Ideology. Information, Communication \& Society 20 (8): 1109-1126.

Entman, R.M. 1993. Framing: Toward Clarification of a Fractured Paradigm. Journal of Communication 43 (4): 51-58.

Emmers, R. 2016. Securitization, in Contemporary Security Studies, ed. Collins, Alan, 168-182. Oxford, Oxford University Press.

Escartin, A.R. 2020. Populist Challenges to EU Foreign Policy in the Southern Neighbourhood: An Informal and Illiberal Europeanisation? Journal of European Public Policy 27 (8): 1195-1214.

European Commission. 2018. Europe: Immigration most important issue facing the EU, Eurobarometer says, 15 June 2018, European Web Site on Integration, available at https://ec.europa.eu/migrantintegration/news/europe-immigration-most-important-issue-facing-the-eu-eurobarometer-says.

Falkner, G., and G. Plattner. 2020. EU Policies and Populist Radical Right Parties Programmatic Claims: Foreign Policy, Anti-Discrimination and the Single Market. JCMS: Journal of Common Market Studies 58 (3): 723-739.

Forchtner, B., Krzyżanowski, M. and Wodak, R. 2013. 'Mediatization, Right-Wing Populism and Political Campaigning: The Case of the Austrian Freedom Party'. In M. Ekström and A. Tolson (eds). Media Talk and Political Elections in Europe and America. London: Palgrave Macmillan UK, pp. 205-228, https://doi.org/10.1057/9781137273321_10.

FPÖ. 2018a. 'Dank HC Strache sind wir zum internationalen Vorbild geworden! Gut für Österreich ', Facebook, available at https://www.facebook.com/fpoe/posts/1222769911197609.

FPÖ. 2018b. 'Im UN-Migrationspakt wird NICHT zwischen legaler und illegaler Migration unterschieden. Innenminister Herbert Kickl ist jedoch genau deshalb angetreten, um diese', Facebook, available at https://www.facebook.com/fpoe/posts/1205883022886298.

FPÖ. 2018c. 'Sehr schön! Auf Herbert Kickl kann man sich verlassen: In der Migrationsfrage wird eine klar erkennbare Linie vorgegeben!', Facebook, available at https://www.facebook.com/fpoe/posts/ 1204540003020600.

Haimbuchner, M. 2018. 'Die Empörung nach unserer Ablehnung des UN-Massenmigrationspaktes hat gezeigt: Wir machen Politik für die Österreicher, nicht für die Globalisten.', Facebook, available at https://www.facebook.com/manfred.haimbuchner/posts/2053751581352174.

Hameleers, M., L. Bos, and C.H. de Vreese. 2017. "They Did It": The Effects of Emotionalized Blame Attribution in Populist Communication. Communication Research 44 (6): 870-900.

Heilbrunn, J. 2016. The New Foreign-Policy Populism. The National Interest 142: 5-9. 
Heinisch, R. and Wegscheider, C. 2018. Die Populisten - Von den Rändern ins Zentrum der Macht, 2018, available at https://quart-online.at/wp-content/uploads/2019/05/q2019_01_38.pdf.

Hettyey, A. 2020. The Europeanization of Hungarian Foreign Policy and the Hungarization of European Foreign Policy, 2010-18. Journal of Contemporary European Studies 0 (0): 1-14.

Homolar, A., and R. Scholz. 2019. The Power of Trump-Speak: Populist Crisis Narratives and Ontological Security. Cambridge Review of International Affairs 32 (3): 344-364.

Huysmans, J. 2000. The European Union and the Securitization of Migration. JCMS: Journal of Common Market Studies 38 (5): 751-777.

Institute for Strategic Dialogue. 2019. ISD research featured in POLITICO about the trolling of the UN migration pact, 3 January 2019, ISD, available at https://www.isdglobal.org/isd-research-featuredin-politico-surrounding-the-trolling-of-the-un-migration-pact/.

IOM. 2017. Global Compact for Migration, 6 March 2017, International Organization for Migration, available at https://www.iom.int/global-compact-migration. Accessed February 2021.

Jansen, R.S. 2011. Populist Mobilization: A New Theoretical Approach to Populism. Sociological Theory 29 (2): 75-96.

Kleine Zeitung. 2018. Absage an UN: Strache zu Migrationspakt: 'Nehmen mutige Vorreiterrolle ein', 31 October 2018, www.kleinezeitung.at, available at https://www.kleinezeitung.at/politik/innenpolit ik/5522592/. Accessed February 2021.

Kickl, H. 2018a 'Aus meiner Sicht durchweht den UN-Migrationspakt eine unglaublich undifferenzierte fast schon naive - positive Auffassung der Migration. Negatives wird ausgeblendet. Es', Facebook, available at https://www.facebook.com/herbertkickl/posts/2184319665179665.

Kickl, H. 2018b. 'Der Wählerauftrag an mich lautet, im Bereich der Asyl- und Migrationspolitik Ordnung zu machen, Klarheit zu schaffen und Kontrolle herzustellen. Das bedeutet, die Solidarität mit der eigenen Bevölkerung', Facebook, available at https://www.facebook.com/herbertkickl/posts/21832 43775287254.

Kickl, H. 2018c. 'Wir haben uns gegen den UN-Migrationspakt und damit für unsere Souverenität ausgesprochen. Genauso wie die USA, Australien, Bulgarien, Ungarn und jetzt auch unsere nördlichen Nachbarn in Tschechien!', Facebook, available at https://www.facebook.com/herbertkickl/posts/ 2199471643664467.

Kickl, H. 2018d. 'Wir müssen darauf achten, dass Migration nicht die Lebenssituation der Österreicherinnen und Österreicher verschlechtert. Das tun wir mit der Ablehnung des UN-Migrationspakts', Facebook, available at https://www.facebook.com/herbertkickl/posts/2192451001033198.

Kickl, H. 2018e. 'Wir wollen nicht, dass der UN-Migrationspakt über die Hintertür in unseren Rechtsbestand einfließt. Daher deklarieren wir uns ganz klar dagegen!', Facebook, available at https://www. facebook.com/herbertkickl/posts/2191810834430548.

Kickl, H. 2018f. 'Ich bin als Innenminister angetreten, um Ordnung im Bereich Asyl und Migration zu machen und diese Ordnung auch zu erhalten. Ich trete für eine restriktive Asyl- und Zuwanderungspolitik', Facebook, available at https://www.facebook.com/herbertkickl/posts/2191359204475711.

Kontrast. 2019. 'Strache auf Facebook: Stimmung gegen Migranten. Nichts zu Mieten, Jobs, Pensionen.', Kontrast.at, available at https://kontrast.at/strache-facebook-analyse/. Accessed February 2021.

Kronezeitung. 2018. Strache: „Nur unserer Bevölkerung verpflichtet“, 31 October 2018, Kronen Zeitung, available at https://www.krone.at/1800225. Accessed February 2021.

Kunasek, M. 2018a. 'Einmal mehr zeigt sich die enorme Wirkung und die starke Handschrift der FPÖ in der Bundesregierung! Österreich hat eine echte Vorreiterrolle übernommen und sich zum Vorbild für zahlreiche Staaten', Facebook, available at https://www.facebook.com/mkunasek/posts/10156 063538568282 .

Kunasek, M. 2018b. 'Vizekanzler HC Strache hat gemeinsam mit Bundeskanzler Sebastian Kurz sichergestellt, dass der äußerst bedenkliche UN-Migrationspakt nicht unterfertigt wird. Es ist unsere', Facebook, available at https://www.facebook.com/mkunasek/posts/10156044330423282v.

Kurier. 2018a. 'Aufregungskultur': Kurz verteidigt Ablehnung von Migrationspakt, 21 November 2018, available at https://kurier.at/politik/inland/nationalrat-kurz-nimmt-stellung-zum-uno-migrations pakt/400330671. Accessed February 2021.

Kurier. 2018b. Kurz: Nein zum Migrationspakt 'nach eingehender Prüfung', 3 November 2018, available at https://kurier.at/politik/inland/kurz-nein-zum-migrationspakt-nach-eingehender-pruefung/40031 3484. Accessed February 2021.

McDonald, M. 2008. Securitization and the Construction of Security. European Journal of International Relations 14 (4): 563-587. 
Mead, W.R. 2017. The Jacksonian Revolt: American Populism and the Liberal Order. Foreign Affairs 96: 2.

Mudde, C. 2007. Populist Radical Right Parties in Europe. Cambridge: Cambridge University Press. https://doi.org/10.1017/CBO9780511492037.

Mudde, C. 2004. The Populist Zeitgeist. Government and Opposition 39 (4): 541-563.

Mudde, C., and C.R. Kaltwasser. 2017. Populism: A Very Short Introduction. Oxford University Press.

Müller, P., Pomorska, K., and Tonra, B. 2021. The Domestic Challenge to EU Foreign Policy-Making: From Europeanisation toDe-Europeanisation? Journal of European Integration 43 (5): 519-534.

Newland, K. 2019. The Global Compact for Safe, Orderly and Regular Migration: An Unlikely Achievement. International Journal of Refugee Law 30 (4): 657-660.

Oels, A. 2012. 'From "Securitization" of Climate Change to 'Climatization' of the Security Field: Comparing Three Theoretical Perspectives'. In J. Scheffran, M. Brzoska, H. G. Brauch, P. M. Link, and J. Schilling (eds). Climate Change, Human Security and Violent Conflict: Challenges for Societal Stability. Berlin, Heidelberg: Springer, pp. 185-205, https://doi.org/10.1007/978-3-642-28626-1_9.

ORF.at. 2018a. Experte Nowak: Ausstieg aus Migrationspakt „fatales Signal“, 31 October 2018, news. ORF.at, available at https://orf.at/stories/3088401/. Accessed February 2021.

ORF.at. 2018b. Nein zu UNO-Migrationspakt: FPÖ jubelt, Opposition und EU bestürzt, 31 October 2018, news.ORF.at, available at https://orf.at/stories/3087941/. Accessed February 2021.

Politico. 2019. How the UN migration pact got trolled - POLITICO, 3 January 2019, POLITICO, available at https://www.politico.eu/article/united-nations-migration-pact-how-got-trolled/. Accessed February 2021.

Profil. 2018. Umfrage: 49\% für Ausstieg aus dem UN-Migrationspakt, 10 November 2018, Profil, available at https://profil.at/oesterreich/umfrage-ausstieg-un-migrationspakt-10460202. Accessed February 2021.

Rheindorf, M., and R. Wodak. 2019. "Austria First” Revisited: A Diachronic Cross-Sectional Analysis of the Gender and Body Politics of the Extreme Right. Patterns of Prejudice 53 (3): 302-320.

Roe, P. 2008. Actor, Audience(s) and Emergency Measures: Securitization and the UK's Decision to Invade Iraq. Security Dialogue 39 (6): 615-635.

Rychnovská, D. 2014. Securitization and the power of threat framing. Perspectives: Review of Central European Affairs 22 (2): 9-32.

Rydgren, J., and S. van der Meiden. 2019. The Radical Right and the End of Swedish Exceptionalism. European Political Science 18 (3): 439-455.

Salter, M.B., and G. Piché. 2011. The Securitization of the US-Canada Border in American Political Discourse. Canadian Journal of Political Science/revue Canadienne De Science Politique 44 (4): 929-951.

Saxony Office for Constitutional Protection. 2016. Verfassungsschutzbericht 2016, available at https:// www.mi.niedersachsen.de/download/119047/Verfassungsschutzbericht_2016.pdf.

Schmidt, V.A. 2019. Politicization in the EU: Between National Politics and EU Political Dynamics. Journal of European Public Policy 26 (7): 1018-1036.

Sohn, Y., and M.G. Koo. 2011. Securitizing Trade: The Case of the KOREA-US Free Trade Agreement. International Relations of the Asia-Pacific 11 (3): 433-460.

Spruyt, B., G. Keppens, and F. Van Droogenbroeck. 2016. Who Supports Populism and What Attracts People to It? Political Research Quarterly 69 (2): 335-346.

Strache, H.-C. 2018a. 'Aus der Basler Zeitung.... Was der ORF und manche österreichische Medien nicht berichten bzw. verschweigen. Das hätte der UN-Migrationspakt für Österreich bedeutet!', Facebook, available at https://www.facebook.com/strache/posts/10217900292918749.

Strache, H.-C. 2018b. 'Der UN-Migrationspakt könnte fatale Folgen haben. Unsere Regierung sieht Österreichs Souveränität gefährdet. HC Strache will deshalb nicht unterschreiben!', Facebook, available at https://www.facebook.com/strache/posts/10217602391871409.

Strache, H.-C. 2018c. 'Der UNO-Migrationspakt "ist nur offiziell auf Initiative der Vereinten Nationen entstanden. Maßgeblich verantwortlich dafür aber zeichnet niemand anderes als Merkels schwarzrotes Kabinett"., Facebook, available at https://www.facebook.com/strache/posts/1021800380 6426522.

Strache, H.-C. 2018d. 'Ich stehe der UNO-Marrakesch-Migrationserklärung, welche bis Dezember 2018 von den EU-Regierungschefs unterfertigt werden soll, absolut kritisch und negativ gegenüber', Facebook, available at https://www.facebook.com/strache/posts/10217482634677554. 
Strache, H.-C. 2018e. 'Linke Globalisten laufen Sturm gegen Österreichs Nein zum UN-Migrationspakt, mittlerweile lehnen auch Staaten wie Israel oder Polen den Vertrag ab. In Deutschland', Facebook, available at https://www.facebook.com/strache/posts/10218079335034690.

Strache, H.-C. 2018f. 'Nach Österreich, den USA, Ungarn und Australien, welche dem UN-Migrationspakt nicht beitreten, beginnen nunmehr auch Tschechien, Kroatien, Italien, Polen, Dänemark, Slowakei, Japan', Facebook, available at https://www.facebook.com/strache/posts/1021792022 4057015.

Strache, H.-C. 2018g. 'Nein zum UNO-Migrationspakt! "Das Papier stammt aus der Feder von Menschen, die offenbar keine Kriminalitätsstatistik gelesen und das Geschäftsmodell der internationalen', Facebook, available at https://www.facebook.com/herbertkickl/posts/2184319665179665.

Strache, H.-C. 2018h. 'Oe24-TV-Interview: Österreich tritt dem UN-Migrationspakt nicht bei. Wer zu uns kommt, entscheiden immer noch wir. Die FPÖ fühlt sich ausschließlich der eigenen Bevölkerung', Facebook, available at https://www.facebook.com/strache/posts/10217908876013321.

Strache, H.-C. 2018i. 'Österreich lehnt den UN-Migrationspakt konsequent ab und ist Vorreiter für zahlreiche andere Staaten! Die FPÖ wirkt jedenfalls in der Bundesregierung. Unter einer SPÖRegierungsbeteiligung', Facebook, available at https://www.facebook.com/strache/posts/10217 925456187815 .

Strache, H.-C. 2018j. 'UNO-Migrationspakt: "Es ist ein gigantischer Vertrag zu Lasten Dritter, bei dem das Programm dynamisch wachsender und unbegrenzter Migrationsförderung ausdrücklich', Facebook, available at https://www.facebook.com/strache/posts/10218071859407804.

Strache, H.-C. 2018k. 'Unsere mutige österreichische Vorreiterrolle zieht immer mehr Länder mit, welche ebenso den UN-Migrationspakt ablehnen!', Facebook, available at https://www.facebook. com/strache/posts/10218087404316417.

Strache, H.-C. 20181. 'Warum wir den UN-Migrationspakt nachhaltig und konsequent ablehnen, die UNFlüchtlings-Resolution jedoch inhaltlich akzeptieren können. In letzter Zeit herrschte viel Konfusion', Facebook, available at https://www.facebook.com/strache/posts/10218168635907156.

Strache, H.-C. 2018m. 'Wir Freiheitlichen stehen der UNO-Migrationserklärung, welche bis Dezember 2018 von den EU-Regierungschefs in Marrakesch akklamiert werden soll, absolut kritisch und bei konkreten Inhalten negativ gegenüber.', Facebook, available at https://www.facebook.com/strache/ posts/10217589636192525.

Strache, H.-C. 2018n. 'Wir haben den UN-Migrationspakt für Österreich erfolgreich verhindert und abgelehnt. Nachdem Merkel zugestimmt hat, darf nunmehr offensichtlich auch im deutschen Fernsehen offen', Facebook, available at https://www.facebook.com/strache/posts/10218227465537860.

Strache, H.-C. 2018o. '"Zugegeben, es sind drastische Worte, die Professor Dan Schueftan, seines Zeichens Sicherheitsberater der israelischen Regierung, gegenüber der Krone gefunden hat', Facebook, available at https://www.facebook.com/strache/posts/10217920969075640.

Strache, H.-C. 2018p. 'Wer zu uns kommt, bei uns arbeiten darf, Sozialleistungen erhält, legal oder illegal einreist, etc., entscheiden immer noch wir!', Facebook, available at https://www.facebook.com/ strache/posts/10217903324834545.

UN. 2016. A/RES/71/1: New York Declaration for Refugees and Migrants, 2016, available at https://www. un.org/en/development/desa/population/migration/generalassembly/docs/globalcompact/A_RES_ 71_1.pdf.

UN. 2018. Un General Assembly - Intergovernmental Conference to Adopt the Global Compact for Safe, Orderly and Regular Migration, 2018, UNDOCS, available at https://undocs.org/A/CONF.231/3. Accessed February 2021.

UNHCR. 2018. Der Globale Pakt für Flüchtlinge, 2018, UNHCR Österreich, available at https://www. unhcr.org/dach/at/was-wir-tun/globaler-pakt. Accessed February 2021.

Varga, M., and A. Buzogány. 2020. The Foreign Policy of Populists in Power: Contesting Liberalism in Poland and Hungary. Geopolitics 0 (0): 1-22.

Verbeek, B., and A. Zaslove. 2015. The Impact of Populist Radical Right Parties on Foreign Policy: The Northern League as a Junior Coalition Partner in the Berlusconi Governments. European Political Science Review 7 (4): 525-546.

Vilimsky, H. 2018a. 'Auch die WerteUnion in der CDU/CSU sieht ein Problem im UNO-Migrationspakt: „Aus unserer Sicht könnte sich der Globale Pakt über', Facebook, available at https://www.faceb ook.com/Vilimsky.Harald/posts/1894839390634999.

Vilimsky, H. 2018b. 'Der UNO-Migrationspakt ,legt an vielen Stellen fest, welche Rechte Migranten überall auf der Welt haben sollen, wo immer sie selbst entscheiden, sich niederzulassen. Kein 
Wort', Facebook, available at https://www.facebook.com/Vilimsky.Harald/posts/1909602585 825346.

Vilimsky, H. 2018c. 'Deutschlands Regierung unter Angela Merkel: Immer dabei, wenn's darum geht, der Migration Gutes zu tun', Facebook, available at https://www.facebook.com/Vilimsky.Harald/ posts/1955873517864919.

Vilimsky, H. 2018d. 'Die EU-Kommission macht Druck auf Österreich und andere EU-Staaten, dem UNO-Migrationspakt zuzustimmen: "Die Kommission soll die Entscheidungen zur Kenntnis nehmen', Facebook, available at https://www.facebook.com/Vilimsky.Harald/posts/1948879085 231029.

Vilimsky, H. 2018e. 'EU-Kommission und EU-Bischofskonferenz fordern jetzt Zustimmung zum UNOMigrationspakt ein. Aber Massenzuwanderung muss man auch dann nicht gut finden, wenn sie "geordnet" abläuft', Facebook.

Vilimsky, H. 2018f. 'Migrationspakt - Immer mehr sagen sich von der Globalisten- und Migrationslobby los. Gut so!', Facebook, available at https://www.facebook.com/Vilimsky.Harald/posts/19029 83956487209.

Vilimsky, H. 2018g. 'Migrationspakt. Auch Polen ist raus. Der nächste Schlag gegen die Globalisten- und Migrationslobby', Facebook, available at https://www.facebook.com/Vilimsky.Harald/posts/19018 46219934316.

Vilimsky, H. 2018h. 'UNO-Migrationspakt: "Es ist ein gigantischer Vertrag zu Lasten Dritter, bei dem das Programm dynamisch wachsender und unbegrenzter Migrationsförderung ausdrücklich', Facebook.

Vilimsky, H. 2018i. 'Wirklich hoch interessant, welche Geheimnistuerei die deutsche Regierung rund um den UNO-Migrationspakt macht. Ein klares Indiz dafür, dass der Ausstieg Österreichs völlig richtig war.', Facebook, available at https://www.facebook.com/Vilimsky.Harald/posts/1913948055 390799.

Vilimsky, H. 2018j. 'Und schon geht's los: Die Migrationsfreunde machen sich an die Überführung des UNO-Migrationspaktes in nationales Recht. Hier die deutschen Grünen.', Facebook, available at https://www.facebook.com/Vilimsky.Harald/posts/1919147164870888.

Vilimsky, H. 2018k. 'UNO-Migrationspakt: "Das Papier stammt aus der Feder von Menschen, die offenbar keine Kriminalitätsstatistik gelesen und das Geschäftsmodell der internationalen', Facebook, available at https://www.facebook.com/Vilimsky.Harald/posts/1910113559107582.

Vilimsky, H. 20181. UNO-Migrationspakt, Meinung eines deutschen Rechtsprofessors: „Die Vereinbarung wird ganz sicher völkerrechtliche Wirkungen haben. “ Der Pakt werde „eine gewisse Sogwirkung, available at https://www.facebook.com/Vilimsky.Harald/posts/1919207794864825.

Weyland, K. 2017. 'A Political-Strategic Approach', The Oxford handbook of populism 48.

Wirz, D.S. 2018. Persuasion Through Emotion? An Experimental Test of the Emotion-Eliciting Nature of Populist Communication. International Journal of Communication 12: 2.

Wodak, R. 2015. The Politics of Fear What Right-Wing Populist Discourses Mean. SAGE.

Wodak, R., J. Culpeper, and E. Semino. 2021. Shameless Normalisation of Impoliteness: Berlusconi's and Trump's Press Conferences. Discourse \& Society 32 (3): 369-393.

Publisher's Note Springer Nature remains neutral with regard to jurisdictional claims in published maps and institutional affiliations.

Patrick Müller is Professor of European Studies at the Institute for Political Science/Center for European Integration Research, University of Vienna and the Vienna School of International Studies. His research interests include the EU's external relations, the EU's role in global governance, EU-Mediterranean relations, and EU conflict resolution.

Charlott Gebauer is a PhD student at Vienna School of International Studies and the University of Vienna. Her research interests include the implementation and transposition of EU legislation, differentiated integration and the policy-cycle dynamic between the EU and its Member States. 